\title{
Regulación de la expresión genética de linfocinas
}

\author{
Vargas A.G. ${ }^{1}$, Granados J. ${ }^{2}$, Llorente P.L. ${ }^{2}$
}

Una vez que se ha establecido la estructura y función de muchas proteínas sintetizadas en el organismo, los investigadores se han dado a la tarea de esclarecer cuáles son los mecanismos que regulan la producción de dichas proteínas.

La cantidad de linfocitos T para coordinar la respuesta inmune refleja su programa de mecanismos autónomos de diferenciación, la cual se induce después de la estimulación antigénica. La activación en la mayoría de las céculas T requiere de dos señales (1): una de ellas está dada por el contacto del receptor de la célula $T$ con el complejo antígeno-SPH (2); esta señal puede ser sustituida utilizando anticuerpos contra el marcador CD3, con lectinas o con ionóforos de calcio; la otra señal está dada por las células accesorias o sus productos de secreción como la IL-1 y/o la IL-6, esta señal puede a su vez ser sustituida por activadores de la proteincinasa $\mathrm{C}$ (PKC) como los ésteres de forbol.

Una vez que se ha hado la activación de la célula $T$, cerca de 100 genes son inducidos para su producción; estos genes han sido clasificados por su homología con genes virales en 3 grupos a saber:

1. Genes de activación inmediatos, los cuales se producen después de 15-30 minutos de activada la célula; entre éstos tenemos a los protooncogenes c-fos y c-myc.

2. Genes de activación temprana, los cuales se producen después de los primeros 30 minu-

1 Alumno de doctorado en la Facultad de Medicina de la UNAM y es apoyado por el Programa Universitario de Investigación en Salud (PUIS) de la UNAM.

2 Investigador en el Departamento de Inmunología y Reumatología del INNSZ. tos hasta las dos horas de activada la célula, entre éstos tenemos a los genes de las linfocinas.

3. Genes de activación tardía, los cuales se producen a los 2 o 14 días después de la activación y entre los cuales tenemos a las moléculas de superficie HLA-DR y VLA (figura 1).

Como podemos ver, la smayoría de las citocinas se encuentran entre los genes de activación temprana y los mecanismos que utiliza la célula para regular su expresión son:

1. Alteración del grado de la transcripción.

2. Terminación de la transcripción.

3. Bloqueo de la transcripción.

4. Estabilidad del RNAm.

De estos mecanismos el que al parecer tiene mayor importancia es el que se da en la transcripción.

Toda esta serie de mecanismos han sido estudiados a través del tiempo en tres etapas las cuales involucran principalmente establecer la estructura del gen en cuestión ayudándose de técnicas de clonación y secuenciación; una vez establecidas las secuencias averiguar cuáles de ellas participan en la regulación, y para ello se construyen genes híbridos que posteriormente se transfectan en diferentes tipos celulares para finalmente identificar las proteínas capaces de unirse a las secuencias reguladoras utilizando ensayos de protección a nucleasa I y ensayos de movilidad electroforética.

\section{Regulación genética de la IL-2}

La gran cantidad de linfocinas que ahora se sabe que existen hace imposible discutir en detalle 


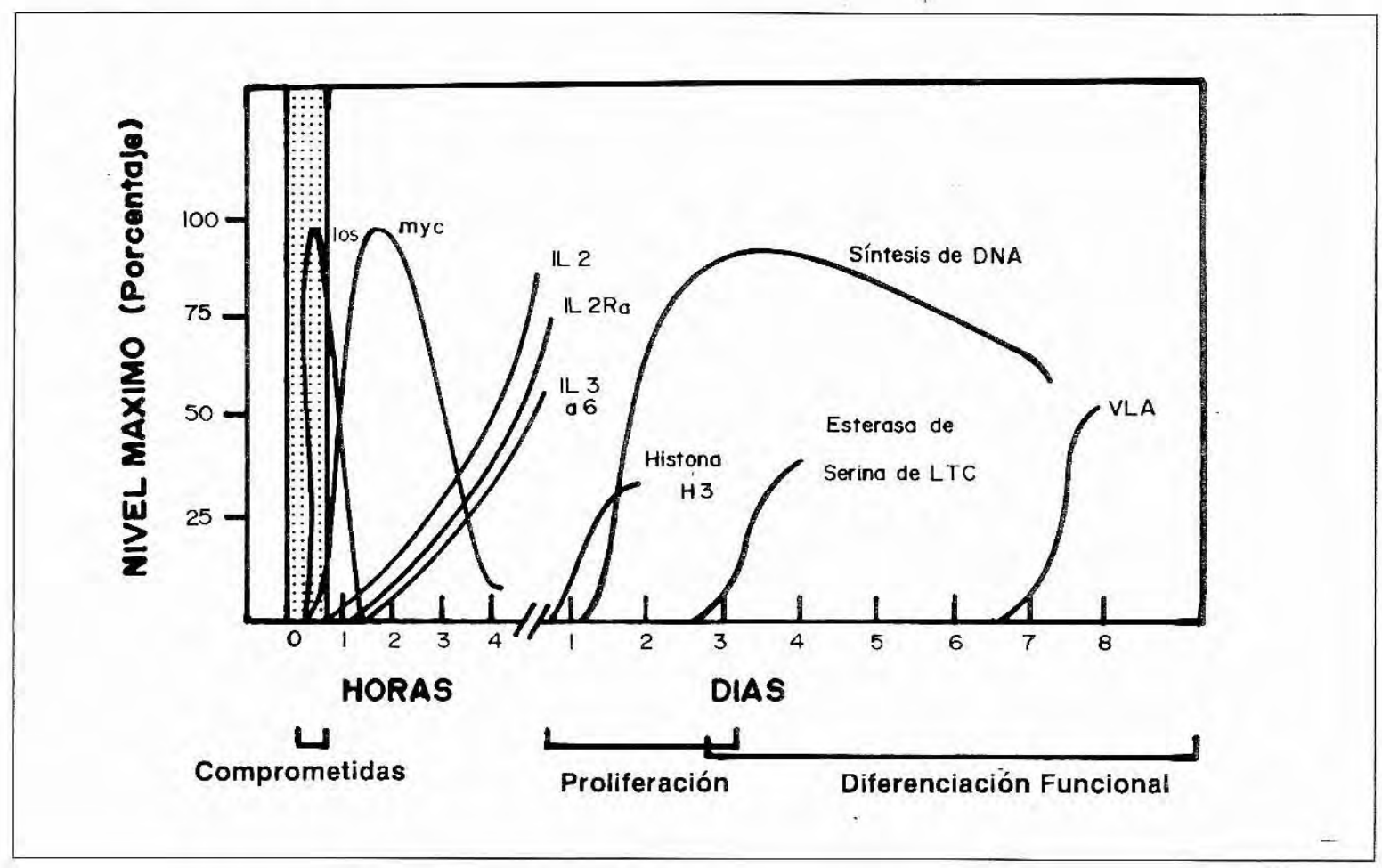

Figura 1. Regulación transcripcional en linfocitos T

cada una de ellas, por lo que tomamos sólo algunas como modelo para discutir sus mecanismos reguladores. De esta serie de linfocinas, la más estudiada es la interleucina 2 (IL-2), debido a que presenta ciertas características importantes, como es el estar bajo control riguroso por el receptor de la célula $T$ (3) mientras que la gran mayoría de los genes de activación tempranos se expresan bajo estímulos menos específicos; esta linfocina posee también un mecanismo preciso de inducción de su propio receptor y éste es esencial para la proliferación y función en la respuesta inmune de la célula T(4).

La estructura cromosómica de la IL-2 fue definida en 1983 por Fujita (5) quien reportó la presencia en este gen de 3 intrones y 4 exones, además de su región promotora que contiene una secuencia palindrómica. Un hecho importante en su estructura es la homología que tiene su región 5 con la región promotora de INF-t (6). Fue hasta 1986 cuando el mismo Fujita (7) estudió la porción 5 del sitio de inicio de la transcripción del gen de IL-2 con el fin de establecer sus posibles secuencias reguladoras, $y$ encontró que la región 5 es la zona donde con mayor frecuencia se localizan las secuencias reguladoras y, por otro lado, es la zona que tiene secuencias de DNA altamente conservadas en varias especies analizadas. En este trabajo de Fujita, se hicieron varios genes híbridos con las secuencias 5 del gen de IL-2 (-551, $-380,-380$, $319,-264,-222,-138,-107$, y -81$)$ y el gen indicador acetil-transferasa-cloramfenicol (AATC); estos genes se transfectaron en células Jurkat (de leucemia humana) y en EL-4 (de timoma de ratón); estas células se estimularon con concanavalina A y con ésteres de forbol respectivamente y se midió la actividad del gen indicador en los extractos nucleares. Se encontró que al utilizar la secuencia de -319 se pierde la inducción por los dos estímulos en ambas células, con lo cual se establece que el límite 5 para la inducción de la expresión se localiza en -319. Con el fin de establecer la importancia funcional 
de la región situada entre -319 y el sitio de inicio de la transcripción, se hicieron cortes internos de la mencionada región, se unieron a ATC y se transfectaron en células EL-4 que fueron posteriormente estimuladas con los ésteres de forbol; posteriormente en los extractos nucleares se midió la actividad del gen indicador. Al hacer el corte de -127 a -81 , la expresión fue adecuada pero al hacer el corte de -145 a -81, se perdió la expresión, lo cual indica que se requiere la secuencia desde -319 hasta - 127 para la expresión adecuada de este gen.

Durand en 1987 (8) utilizando una metodología semejante a la de Fjujita, es decir, formando genes híbridos y transfectándolos en células Jurkat estableció la participación de una secuencia de 275 sb (-326 a -52) de la región 5 del gen de IL-2. Con el fin de establecer si este fragmento recibe señales del receptor de la célula $T$, las células transfectadas con una secuencia que contenía la región de -326 a - 52 de IL-2, la región promotora del fibrinógeno y el gen ATC, recibieron varios estímulos. Unicamente se detectó expresión cuando los estímulos incluían ambas señales requeridas para la activación (discutidas anteriormente) (tabla 1). Una vez identificado el fragmento de $275 \mathrm{pb}$ se examinaron subfragmentos de esta región, un fragmento $A(-326$ a -164) y un fragmento $B(-164$ a -51) y se encontró que únicamente hay expresión del gen cuando existen dos copias de los fragmentos anteriores, ya sea los mismos o uno de cada uno. Una vez demostrada la existencia de una subunidad duplicada funcional, se trató de definir las secuencias activas en los fragmentos, $A$ y $B$ haciendo cortes internos de la secuencia y transfectando en células Jurkat que son activadas posteriormente. Al eliminar algunos fragmentos la expresión disminuye y por tanto éstos podrían ser sitios importantes en la función del activador de IL-2 y podrían ser sitios de unión para factores transcripcionales presentes en los extractos nucleares de las células. La presencia de estos factores de unión a las anteriores secuencias se estudió usando ensayos de protección a nucleasa I y se identificaron 5 regiones protegidas que se definieron como $A, B, C, D, E$ y $F$ partiendo del sitio de inicio de la transcrip-
Tabla 1. Efecto de estímulos sobre la expresión de IL-2.

\begin{tabular}{lcc}
\hline Estímulo & \% Conversión & Inducibilidad \\
\hline & 0,18 & - \\
Anti T1 + PMA & 0,40 & + \\
Anti T1 & 0,20 & - \\
PMA & 0,20 & - \\
Anti HLA + PMA & 0,20 & - \\
Anti HLA & 0,23 & - \\
PHA + PMA & 0,69 & + \\
A23187 + PMA & 1,00 & + \\
A23187 & 0,25 & - \\
\hline
\end{tabular}

Fuente: (9)

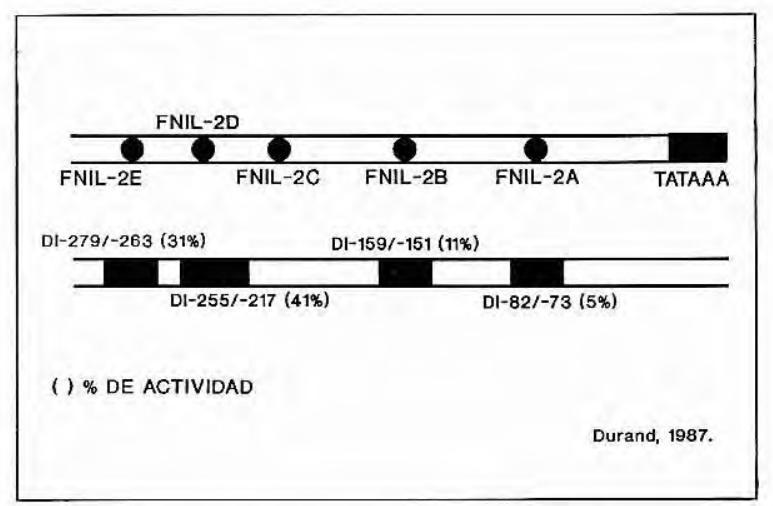

Figura 2. Sitios protegidosen el fragmento de $275 \mathrm{pb}$.

ción (figura 2) (9). Los sitios A y D son protegidos con extractos nucleares de células no estimuladas, mientras que el sitio E sólo es protegido con extractos nucleares de células estimuladas lo cual se relaciona con un estado de activación. Por ensayos de competición se pudo demostrar que la proteína que se une al sitio $D$ y al sitio $A$ son muy semejantes o la misma. Con el fin de establecer si los sitios A y E responden a señales del receptor de la célula $T$, se formaron genes híbridos con estos sitios y se determinó la capacidad de expresión utilizando diversos estímulos. Ninguno de los sitios responde a ésteres de forbol solos; ambos sitios responden a anticuerpos contra CD3 o fitohemaglutinina (PHA) solos; de tal forma que ambos sitios responden a señales del receptor de la célula $T$ y no responden a estímulos dados por PKC. En suma, se identifi- 
caron dos sitios importantes en el activador de IL2 que responden a señales del receptor de la célula $T$. Ya que el sitio $E$ sólo es protegido con extractos de células activadas, se deduce que este sitio se relaciona con la activación. Las proteínas unidoras de los sitios $A$ y E se llamaron NFIL-2A y NFIL-2E (NFAT-1) respectivamente y se demostró que el NFAT-1 aparece 10 a $25 \mathrm{~min}$ antes de que aparezca el RNAm para iL-2 (10) por lo cual se cree que la activación de IL-2; es dependiente de la anterior activación del NFTA1 , además de que la eliminación del sitio de unión de NFTA-1 altera la activación del gen de IL-2, este sitio de unión unido a un promotor no relacionado puede hacer a este promotor específico de células $T$ y respondedor a señales del receptor de la célula $T$. Se sabe que la ciclosporina $A$ bloquea la activación del gen de IL-2 (11) y la capacidad del sitio $\mathrm{E}$ a activar un promotor en respuesta a señales del receptor de la célula $T$, y la actividad de unión de NFTA-1 aumenta 50 veces en células estimuladas.

Otros sitios de unión para proteínas reguladoras son el sitio -240 de unión a AP1 en células EL-4 (12) y el sitio -206 a -195 de unión a NFKB (13). Para saber si este último sitio de unión funciona en la inducción del promotor de II-2, se cambiaron algunas bases de él, se ligaron al gen ATC y se transfectaron en células Jurkat las cuales fueron estimuladas con PHA y con ésteres de forbol. Al hacer cualquier modificación en esta secuencia, se lleva a una falta de expresión con lo que se concluye que esta secuencia es importante en el promotor del gen IL-2. En este mismo trabajo, se identificaron proteínas de $80-90$ y 50 $55 \mathrm{Kd}$ que se unen a esta secuencia y que son semejantes a las que se unen a una secuencia $\mathrm{KB}$ en el virus HIV-I.

En resumen, para que se lleve a cabo la invitación del gen de la IL-2, se requiere de la presencia a nivel del gen de, por lo menos, cuatro secuencias reguladoras que son los sitios $A, E$, $\mathrm{KB}$ y de respuesta a ésteres de forbol, así como de sus respectivas proteínas unidoras que son NFIL-2A, NFAT-1, NFKB y AP-1 respectivamente. La señal dada por el contacto con el RCT o estímulos semejantes lleva a la producción de la proteína NFIL-2A que se une al sitio A y de ia proteína NFAT-1 que se une al sitio E por mecanismos aún desconocidos; la segunda señal dada por las células accesorias o mecanismos semejantes y que activan a la PKC llevan a la producción de la proteína AP-1 y KB. Al llevarse a cabo la unión de las diferentes proteínas nucleares con sus respectivas secuencias reguladoras a nivel del promotor del gen, se activa el proceso de transcripción y se llega finalmente a la producción de la IL-2.

\section{Regulación genética de los interferones}

Otra serie de factores solubles estudiados con respecto a su regulación son los interferones. En 1985, Ryals (14) usando ensayos de transfección en células de ratón LMTK, identificó una región de $46 \mathrm{pb}$ en el extremo 5 del sito de inicio de la trasncripción en el gen del INF- $\alpha$ y que al parecer es altamente conservada con respecto al gen de INF-B. Esta región abarca de -64 a-109 e incluye una serie de dos pentámeros y dos octámeros que se definen como elementos de respuesta a virus (ERV).

Fujita en 1985 (15) usando mutuaciones del gel de INF- $\beta$ unidas al gen indicador de la globina- $\beta$ y transfectadas en células L929 (línea de fibroblastos); estableció la participación de una secuencia en la región 5 que presenta 7 hexámeros repetidos. Goodbour (16) en ese mismo año utilizando híbridos de INF- $B$ y globina- $B$ en células $\mathrm{C} 127$ activadas con RNA de doble cadena localizó una región de 40 pb que abarca de -77 a -37 y que llamó elemento de respuesta a INF (ERI), esta secuencia tiene las características típicas de un activador de la transcripción, es decir, puede activar la transcripción de este gen independientemente de su posición y orientación con respecto al sitio de inicio de la transcripción. En este trabajo se encontró que cualquier alteración en esta secuencia lleva a una disminución de la expresión.

En 1986, el mismo Goodbour junto con Maniatis (17) hicieron cortes internos del ERI y las unieron al promotor de timidincinasa(Tk) transfectándolas en células $\mathrm{C127}$; los cortes abarcaron la secuencia de -36 a -77. En este trabajo se detectó un elemento regulador negativo que abarca de -36 a -55 . Esto se supo ya que al eliminarlo, la 
induccción del gel indicador aumentó. Se cree que este elemento actúa para mantener un nivel bajo de la transcripción; la secuencia restante de -55 a -77 se considera que es un elemento transcripcional constitutivo. Este mismo grupo en 1988 (18) estableció los dominios de esos elementos haciendo cortes de la secuencia o ERI (figura 3). Se localizan en ella dos dominios reguladores positivos (DRP) de -77 a-64 (DRP1) y de -66 a -55 (DRP2), así como también un dominio regulador negativo (DRN) de -36 a -63 . El mismo Maniatis (19) detectó las proteínas unidoras de esos elementos utilizando ensayos de protección a nucleasa I (tabla 2). Posteriormente, Visvanathan (20) estableció que el factor NF-KB es la proteína que se une al dominio regulador positivo 2 (DRP2). Leonardo en 1989 (21) corroboró esto haciendo ensayos de competición.

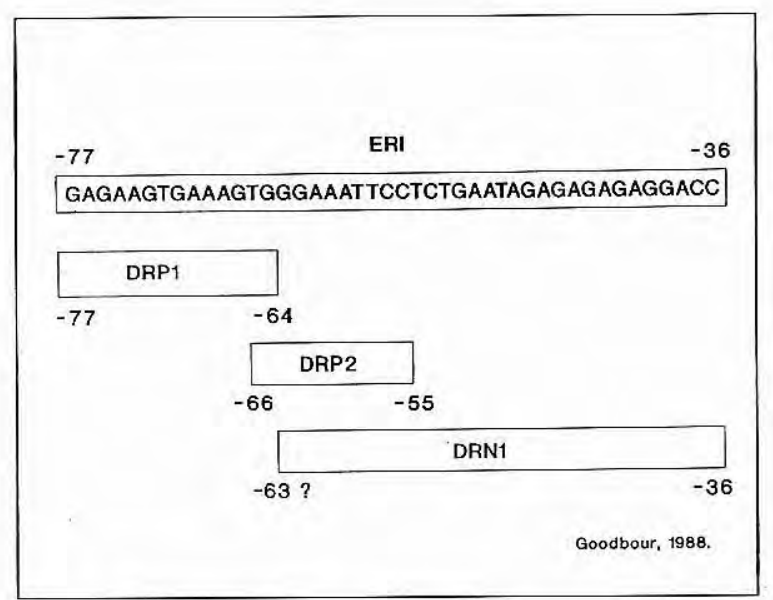

Figura 3. Dominios positivos y negativos en el ERI.

Tabla 2. Proteinas unidoras al ERI.

\begin{tabular}{cll}
\hline Inducción (RNAdc) & Proteina & Sitio \\
\hline- & PUc-DRP1 & DRP1 \\
- & PUc-DRP2 & DRP2 \\
+ & PUc-DRP1 & DRP1 \\
+ & PUc-DRP2 & DRP2 \\
+ & PUi-DRP1 & DRP1 \\
\hline
\end{tabular}

Fuente: (19)
Una vez establecidas las secuencias y proteínas importantes en la regulación del INF- $B$, se puede proponer un modelo de regulación en el cual se puede establecer que en una célula en reposo dada, el dominio regulador negativo está ocupado por la proteína unidora y ésta por efecto estérico no permite la unión de las proteínas a los dominios reguladores positivos, impidiendo por lo tanto la transcripción del gen en cuestión. Cuando la célula es activada, la proteína de regulación negativa se despega de su sitio de unión y con ello permite que las proteínas de regulación positiva se unan a sus respectivos sitios y de esta manera se lleve a cabo la transcripción y la producción de la linfocina.

En 1987, Hardy (22) estableció la presencia de un elemento regulador positivo (-215 a -53) así como también de un elemento regulador negativo $(-251$ a -215), ambos ubicados en el gen del INF-t; estos experimentos se hicieron en células mononucleares de sangre periférica.

\section{Regulación genética de IL-6}

En 1987, Yasukawa (23) estableció la estructura del gen de IL-6, el cual está formado por 5 exones y 4 intrones los que al parecer tienen homología con el factor estimulador de colonias granulocíticas. El gen presenta múltiples sitios de inicio, tres de los cuales ya fueron identificados.

Al parecer la inducción de IL-6 por citonas o virus es mediada por una secuencia de $115 \mathrm{pb}$ ubicada entre -225 y -111 , la cual fue detectada usando ensayos de acetil transferasa cloramfenicol (24). Los autores indentificaron en esta región, un elemento regulador múltiple de 23 pb (-173 a 151) en el cual convergen señales de transducción de IL-1, FNT, PKA y de PKC. Otro elemento de respuesta a IL-1 fue ubicado por Kishimoto en 1990 (25) en la región de -180 a -111 pb por. La inducción de IL-6 por el FNT o por la IL-1 es mediada por un factor semejante a NF-KB el cual se une a una secuencia de sólo 10 pb (-73 a -64) ubicadas cerca de la región TATA. Así, tres regiones en el promotor de IL-6 son identificados como dominios funcionales los que están involucrados en su regulación (figura 4). 


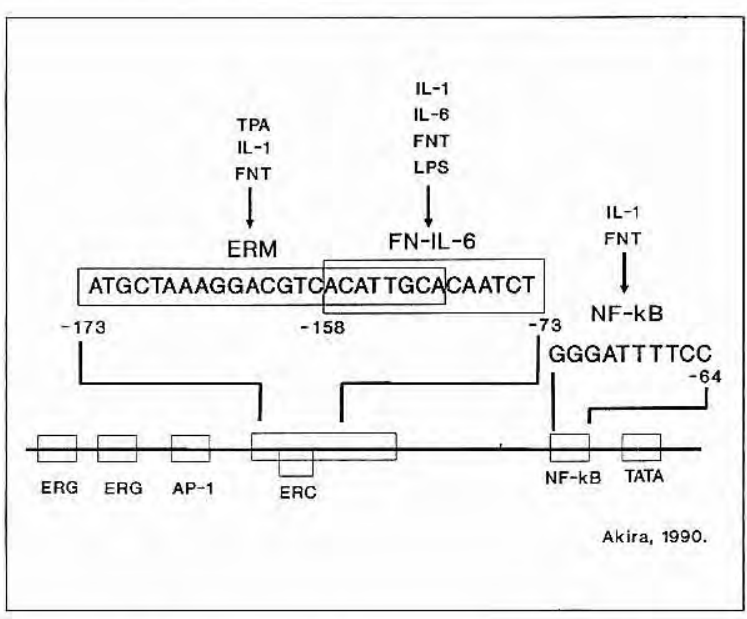

Figura 4. Regiones reguladoras en el gen de IL-6.

\section{Conclusiones}

De los trabajos anteriores se puede concluir que las secuencias reguladoras de los diferentes genes de linfocinas se localizan básicamente en la porción 5 que flanquea el sitio de inicio de la transcripción. Estas secuencias pueden ser tanto de regulación positiva como negativa, existiendo proteínas capaces de unir dichas secuencias. De estas proteínas unidoras se han podido definir únicamente aquéllas que se unen a las regiones reguladoras positivas; de las que se unen a las regiones reguladoras negativas se sabe que existen pero no han podido ser aisladas. La presencia en los genes estudiados de secuencias con gran homología hace pensar que estos distintos genes son regulados por mecanismos muy semejantes. La mayoría de los estudios se han realizado en líneas tumorales de células $T$, las cuales son variables en cuanto a calidad y cantidad con respecto a su respuesta de linfocinas; así se sabe, por ejemplo, que una linfocina puede ser regulada de diferente forma en dos líneas celulares distintas dependiendo de su capacidad de producir las proteínas reguladoras y dependiendo también de su estado de desarrollo; lo anterior obliga a ser cautelosos al comparar los resultados obtenidos in vitro con lo que sucede normalmente in vivo, por lo menos en lo que respecta a los mecanismos de regulación, sin embargo, debe considerarse como un gran adelanto, la obtención de estos conocimientos.

\section{Referencias}

1. Rosenstreich D, Mizel S. Signal requirements for $T$ lymphocyte activation. I. Replacement of macrophage function with phorbol myristate acetate. J Immunol 1979; 123:1749.

2. Davis MM, Bjorkman PJ. T cell antigen receptor genes and T cell recognition. Nature 1988; 334:395.

3. Depper JM, Leonard WJ, Drogula C, Greene WC, et al. Interleukin 2 (IL-2) augments transcription of the IL2 receptor gene. Proc Natl Acad Sci USA 1985; 82:4230.

4. McCrady CW, Ely CM, Westin E, Carchman RA. Coordination and reversibility of signals for proliferative activation and interleukin-2 mRNA production in resting human $\mathrm{T}$ lymphocytes by phorbol ester and calcium ionophore. J Biol Chem 1988; 263:18537.

5. Fujita T, Takaoka C, Matsui H, Taniguchi T. Structure of the human interleukin 2 gene. Proc Natl Acad Sci USA 1983; 80:7437.

6. Gray PW, Goeddel DV. Structure of the human immune interferon gene. Nature 1982; 298:859.

7. Fujita T, Shibuya H, Ohashi T, Yamanishi K, Taniguchi T. Regulation of human interleukin 2 gene: functional DNA sequences in the $5^{\prime}$ flanking region for the gene expression in activated Tlymphocytes. Cell 1986; 46:401.

8. Durand DB, Bush MR, Morgan JG, Weiss A, Crabtree GR. A 275 basepair fragment at the $5^{\prime}$ end of the interleukin 2 gene enhances expression from a heterologous promoter in response to signals from the $T$ cell antigen receptor. J Exp Med 1987; 165:395.

9. Durand DB, Shaw JP, Bush MR, Crabtree GR. Characterization of antigen receptor response elements with in the interleukin-2 enhancer. Mol Cell Biol 1988; 8:1715.

10. Shaw JP, Utz PJ, Durand DB, Crabtree GR. Identification of a putative regulator of early $T$ cell activation genes. Science 1988; 241:202.

11. Elliott JF, Lin Y, Mizel SB, et al. Induction of interleukin 2 messenger RNA inhibited by cyclosporin A. Science $1984 ; 226: 1439$.

12. Angel $P$, Imagawa M, Chiu R, Karin M, et al. Phorbol ester-inducible genes contain a common cis element recognized by a TPA-modulated trans-acting factor. Cell 1987; 49:729.

13. Hoyos B, Ballard DW, Bohnlein E, Siekevitz M, Greene WC. Kappa B-specific DNA binding proteins: role in the regulation of hyman interleukin-2 gene expression. Science 1989; 244:457.

14. Ryals J, Dierks P, Ragg H, Weissmann C. A 46nucleotide promoter segment from an IFN-a gene renders an unrelated promoter inducible by virus. Cell 1985; 41:497.

15. Fujita T, Ohno S, Yasumitsu H, Taniguchi T. Delimitation and properties of DNA sequences requered for the regulaied expression of human interferon-b gene. Cell 1985: 41:489. 
16. Goodbourn S, Zinn K, Maniatis T. Human b-interferon gene expression is regulated by an inducible enhancer element. Cell 1985; 41:509.

17. Goodbourn S, Burstein H, Maniatis T. The human binterferon gene enhancer is under negative control. Cell 1986; 45:601.

18. Goodbourn S, Maniatis T. Overlapping positive and negative regulatory domains of the human b-interferon gene. Proc Natl Acad Sci USA 1988; 85:1447.

19. Keller AD, Maniatis T. Identification of a inducible factor that binds to a positive regulatory element of the human b-interferon gene. Proc Natl Acad Sci USA 1988; 85:3309.

20. Visvanathan KV, Goodbourn S. Double-stranded RNA activates binding of NF-kB to an inducible element in the human b-interferon promoter. EMBO J 1989; 8:1129.
21. Leonardo MJ, Fan CM, Maniatis T, et al. The involvement of NF-kB in b-interferon gene regulation reveals its role as widely inducible mediator of signal transduction. Cell 1989; 57:287.

22. Hardy KJ, Manger B, Newton M, Stobo JD. Molecular events involved in regulating human interferon-t gene expression during $\mathrm{T}$ cell activation. J Immunol 1987; 138:2353.

23. Yasukama K, Hirano T, Watanabe $\mathrm{Y}$, et al. Structure and expression of human $\mathrm{B}$ cell stimulatory factor-2 (BSF-2/IL-6) gene. EMBO J 1987; 6:2939.

24. Akira S, Hirano T, Taga T, Kishimoto T. Biology of multifunctional cytokines: IL- 6 and related molecules (IL-1 and TNF). FASEB J 1990; 4:2860.

25. Kishimoto T. B-cell stimulatory factors (BSFs): Molecular structure, biological function, and regulation of expression. J Clin Immunol 1987; 7:343. 